\title{
Inorganic Coordination Chemistry: Where We Stand in Cancer Treatment?
}

\author{
Pedro Pedrosa, Andreia Carvalho, \\ Pedro V. Baptista and Alexandra R. Fernandes \\ Additional information is available at the end of the chapter
}

http://dx.doi.org/10.5772/intechopen.80233

\begin{abstract}
Metals have unique characteristics such as variable coordination modes, redox activity, and reactivity being indispensable for several biochemical processes in cells. Due to their reactivity, their concentration is tightly regulated inside the cells, and abnormal concentrations are associated with many disorders, such as cancer. As such metal complexes turned out to be very attractive as potential anticancer agents. The discovery of cisplatin was a crucial moment, which prompted the interest in $\mathrm{Pt}(\mathrm{II})$ and other metal complexes as potential anticancer agents. This chapter highlights the state of the art on metal complexes in cancer therapy, highlighting their uptake mechanisms, biological targets, toxicity, and drug resistance. Finally, based on the importance of selective target of cancer cells, drug delivery systems will also be discussed.
\end{abstract}

Keywords: cancer therapy, metal complexes, mechanism of action, clinical trials, platinum, ruthenium, copper

\section{Introduction}

Metal compounds are of undeniable importance to medicine, either for their toxicity or for their effectiveness in disease treatment. In ancient Egypt, copper was used to reduce inflammation and iron to treat anemia [1]. In modern medicine, noticeable discoveries of metal-based compounds marked the last centuries such as $\mathrm{K}\left[\mathrm{Au}(\mathrm{CN})_{2}\right]$, by Robert Koch, at around 1890, to treat tuberculosis; arsphenamine developed in the 1910s to cure syphilis; and Cisplatin discovered by Barnett Rosenberg in the late 1960s as an anticancer agent [2]. The latter marked a milestone in drug discovery for inorganic complexes, revolutionizing cancer 
treatment and shifting focus to rational design to improve metal-based drugs, where other coordination compounds (e.g., gold, ruthenium, titanium, and copper) were also explored with some reports of (pre)clinical and clinical candidates [3, 4].

Transition metals, such as zinc, iron, and copper, are involved in several biological processes, from electron transfer to enzyme cofactors meaning that their intracellular concentration is tightly regulated, otherwise it can lead to the development of various pathological disorders such as Menkes and Wilson diseases associated with copper impairment and accumulation, respectively [4]. A common characteristic of these metals is their ability to form reactive oxygen species (ROS), which are a part of cellular redox balance and fundamental in cell metabolism, signal transduction for proliferation, differentiation, and cell death, among others [3]. Redox homeostasis is controlled by compartmentalizing reactions in the cell in subcellular units such as mitochondria and peroxisomes [3]. It is therefore understandable the great impact that metal complexes can have on such redox balance. Disturbing the oxidant-antioxidant balance promotes an oxidizing environment leading to oxidative stress. When ROS are formed inside the cells, they can induce the lipid peroxidation of cell membranes, disrupt the mitochondrial membrane potential promoting membrane depolarization, induce DNA single-strand breaks, and oxidize the cysteine residues resulting in protein structural changes [3]. Cancer cells are known to have a different redox metabolism from normal cells, with augmented levels of intracellular ROS, mostly due to increased metabolic activity and hypoxia, especially in the core of solid tumors [4]. Metal complexes, due to their redox properties, have been shown to disturb cellular redox homeostasis resulting in enhanced levels of oxidative stress prompting cancer cell death [4-8].

DNA is the main intracellular target for a high number of anticancer metal complexes (e.g., cisplatin, carboplatin, and oxaliplatin); however, several other targets are known (Figure 1) [4].

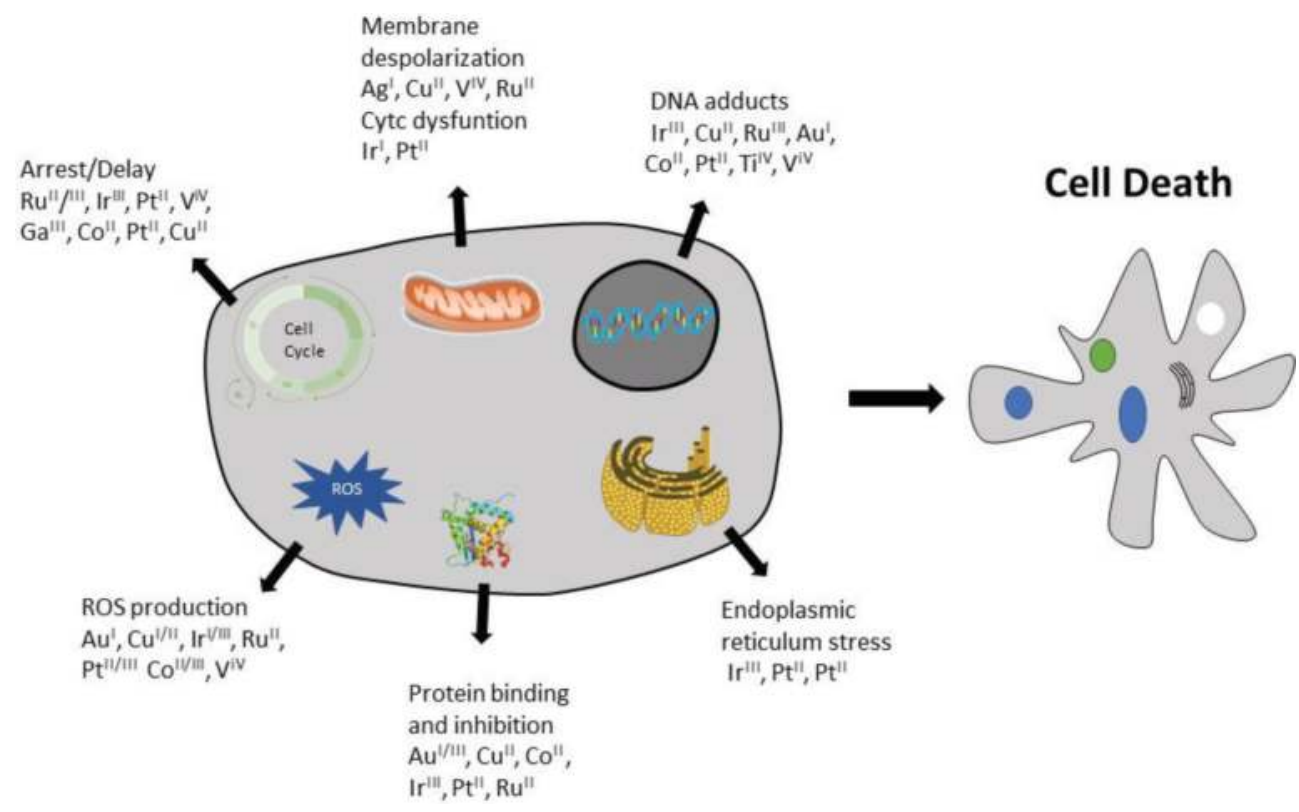

Figure 1. Schematics of metal complex mechanisms of action that promotes cell death. 
In the following sections, we will summarize the current knowledge on $\mathrm{Pt}, \mathrm{Au}, \mathrm{Ru}, \mathrm{Ti}, \mathrm{Pd}, \mathrm{Ir} \mathrm{Cu}$, $\mathrm{V}, \mathrm{Co}, \mathrm{Ga}$, and Os complexes, highlighting their uptake mechanisms, biological targets, toxicity, and drug resistance mechanisms and elucidating how far they are from translation to the clinics in cancer therapy.

\subsection{Platinum}

Platinum-containing complexes revolutionized cancer treatment since the introduction of cisplatin. Synthesized in 1844, it was used for the first time, more than 100 years later to treat patients with testicular cancer with survival rates over 90\% [9]. Since then, more than 3000 platinum derivatives were synthesized and tested for antiproliferative potential against cancer cells. Today, there are six platinum drugs approved in cancer treatment, three of them-cisplatin, carboplatin, and oxaliplatin - by Food and Drug Administration (FDA) and used worldwide and the other three approved in specific countries-nedaplatin in Japan, lobaplatin in Korea, and heptaplatin in China [10]. Platins are the first-line therapeutics in several cancers either alone, in combination with radiotherapy, or with other antitumor or antiangiogenic drugs $[9,11,12]$. Their cellular effects result from four main steps: (i) internalization, (ii) aquation, (iii) formation of DNA adducts, and (iv) cell response (either survival or apoptosis) [13]. Once inside the cells, the ligands (chloride in cisplatin, dicarboxylate in carboplatin, and oxalate in oxaliplatin) are substituted by water molecules that interact with nucleophilic centers on purine bases of DNA, promoting not only cross-linking of the N7 sites of adjacent guanine nucleobases, but also interstrand crosslinks, inducing severe structural distortion of the double helix. This stalls DNA transcription and arrests the cell cycle at the G2/M transition. DNA repair machinery is recruited, and if unable to repair, cells trigger apoptotic cell death [13]. However, some cells enhance their DNA repair activity becoming resistant to cisplatin that have been associated with patient's relapse [14, 15]. Other DNA damage-independent processes have been proposed such as destabilization of redox homeostasis by increasing the intracellular levels of ROS. Cisplatin metabolism is in part performed by glutathione leading to its decrease, affecting NADPH pools, resulting in dysfunctional mitochondrial redox status, and causing ROS [16]. For all FDA approved platins, the mechanism of action is believed to be very similar, with incremental variations $[17,18]$. Carboplatin has less toxicity than cisplatin because 1,1-cyclobutanedicarboxylate is a poorer leaving group than chloride lowering its potency being primarily used for ovarian cancer treatment [19]. Oxaliplatin was the latest approved platinum drug and is a part of the first-line treatment for colorectal cancer. In contrast to cisplatin and carboplatin, oxaliplatin features a quelating nonleaving group, 1,2-diaminocyclohexane (DACH) in place of the two monodentate amine ligands. It also features a bidentate chelating oxalate leaving group ligand [19]. Oxaliplatin does not form adducts as efficient as cisplatin, but the hydrophobicity and size of the DACH group make it more efficient in inhibiting DNA polymerization and repair [3]. Oxaliplatin cellular uptake is active and through copper transporters 1 and 2 and organic cation transporters (OCTs) 1 and 2; the latter explains its efficacy against colorectal cancer (with OCTs overexpression) [9]. Nedaplatin features cis ammine nonleaving group ligand (glycolate), associated with its greater water solubility. It has less toxicity than cisplatin and less nephrotoxic and is mainly used in combination therapy to manage urological tumors [20].

Heptaplatin features malonate as a chelating leaving group ligand and a chelating 2-(1-methylethyl)-1,3-dioxolane-4,5-dimethanamine nonleaving group ligand, which forms a seven-membered chelate ring. It is used for gastric cancer, but its advantage over cisplatin 
has controversial results in clinical trials [11]. Lobaplatin, a derivative of heptaplatin, fuses a cyclobutene ring to the seven-membered chelate ring instead of a dioxolane with an S-lactate as a leaving group ligand. It was originally approved to manage patients with chronic myelogenous leukemia, small-cell lung cancer, and metastatic cancer showing noncross-resistance to cisplatin [21]. Phase I clinical trial is undergoing to expand its use in combination therapy in solid tumors [22].

Currently, there are other platinum drugs in clinical trials: satraplatin, picoplatin, and two polymer/liposomal-based platinum drugs-ProLindac and Lipoplatin. Satraplatin, bis-(acetato) -ammine-dichloro-(cyclohexylamine) platinum(IV), was enrolled in several Phase I, II and III clinical trials mainly in conjunction with other drugs (e.g., docetaxel, paclitaxel, and capecitabine), but all have been recently terminated or concluded. Satraplatin was administered orally, absorbed by the gastrointestinal mucosa, and reduced in the bloodstream into more than six different $\mathrm{Pt}(\mathrm{II})$ complexes of which cis ammine dichloride(cyclohexylamine)-platinum(II) is the most important and showed anticancer activity against platinum sensitive and resistant cell lines. One of the most relevant Phase III trials evaluated a combination of satraplatin and prednisone against hormone refractory prostate cancer who had progressed after initial chemotherapy. In this study, $40 \%$ of patients had reduced risk of prostate cancer progression [23].

Picoplatin, cis-ammine-dichloride(2-methylpyridine) platinum(II), has a pyridine ring nearly perpendicular to the platinum plane, thus positioning the ligand's methylpyridine in a position that protects the metal center from nucleophilic attacks, specially by thiols. It has shown ability to overcome platinum drug resistance [23]. In Phase I clinical trials, picoplatin showed some side effects such as neutropenia, thrombocytopenia, nausea, and vomiting; however, no neuro- or nephrotoxicity was observed, and in three different Phase II clinical trials, it showed reduced efficacy as first- and second-line therapy. It is currently undergoing Phase I and Phase II studies as a combination therapy for colorectal cancer [24, 25].

Lipoplatin is a liposomal nanoparticle formulation of cisplatin with dipalmitoyl phosphatidyl glycerol (DPPG), soy phosphatidyl choline (SPC-3), cholesterol, and methoxy polyethylene glycol (mPEG2000)-distearoyl phosphatidylethanolamine (DSPE). The PEG allows cisplatin to evade the immune system increasing the circulation time. Lipoplatin fuses with cancer cells through DPPG, a fusogenic lipid embedded in the lipid bilayer allowing the release of cisplatin inside the cytoplasm of tumor cells [26]. It has successfully finished Phase III clinical trials showing superior effects when in combination with paclitaxel compared to cisplatin. Due to enhanced permeability and retention (EPR) effect, the nanoparticles are concentrated inside the tumor with 40- to 200-fold higher platinum concentration than healthy tissues [26].

ProLindac is a nanopolymer composed of $[\mathrm{Pt}(\mathrm{R}, \mathrm{R}-\mathrm{dach})]$, the active group of oxaliplatin, bound to an hydrophilic biocompatible polymer [hydroxypropylmethacrylamide (HPMA)] to better increase tumor targeting by EPR. The polymer segments are connected by amidomalonate chelating group and a triglycine spacer. The amidomalonate-platinum chelate bond breaks at low $\mathrm{pH}$ for releasing platinum complex in the hypoxic tumor microenvironment. ProLindac showed activity against cisplatin resistant cell lines [27]. Clinical trials showed no acute significant adverse effects. ProLindac has currently finished Phase II in combination with paclitaxel in the second-line treatment of pretreated advanced ovarian cancer with $66 \%$ of all patients achieving disease stabilization [27]. 
Despite all advances, platinum complexes still suffer from severe side effects as well as intrinsic or acquired multidrug drug resistance (MDR), limiting its applications. To surpass this, novel strategies are being explored. Some examples include the "rule-breaking" platinum compounds: complexes with glucose ligands, complexes that display trans geometries [28], positively charged molecules, $\mathrm{Pt}(\mathrm{IV})$ prodrugs that become reduced to $\mathrm{Pt}(\mathrm{II})$ inside the cells, and photoactive molecules, among others [6, 29]. Of those we will highlight three approaches, first the tentative to vectorize Pt(II) to cancer cells through glucose as a ligand. Cancer cells overexpress glucose transporters making them an ideal target for active therapy [29]. Patra and coworkers showed that this is a viable conjugation with increased accumulation of platinum in tumor cells and comparable efficacy in vivo with oxaliplatin [29]. Later, Lippard et al. described a Pt(IV)(D)-1methyltryptophan conjugate coupled with an indoleamine-2,3-dioxygenase (IDO) ligand. IDO is an inhibitory immune checkpoint target that enhances antitumor immune response, thus increasing the efficacy of common chemotherapeutics and radiotherapy. This prodrug killed hormone-dependent, cisplatin resistant, and human ovarian cancer cells, by deregulating the autocrine-signaling loop IDO-AHR-IL6 and paving the way to new platinum immunechemotherapy [30]. A photoactive platinum(IV) anticancer complex trans-[ $\left.\mathrm{Pt}\left(\mathrm{N}_{3}\right)_{2}(\mathrm{OH})_{2}(\mathrm{Py})_{2}\right]$ was used in photodynamic therapy. Upon irradiation with blue light, it binds to amino acid residues of thioredoxin, a multifunctional enzyme that regulates gene transcription, redox signaling, and cell growth, inhibiting cell apoptosis, overexpressed in several cancers, leading to an increase oxidative stress persistent for more than $48 \mathrm{~h}$ in vitro, with a potent antiproliferative activity. The complex might be suitable for treatment of peripheral cancers such as bladder and esophageal [10,31].

\subsection{Ruthenium}

Ruthenium complexes are already recognized as an effective alternative to platinum complexes, providing different mechanisms of action, different spectrum of activities, and potential to overcome platinum associated MDR [32]. Ruthenium has numerous properties: (i) they can exist in multiple oxidation states (II, III, and IV), all accessible under physiologic conditions, an advantage in the reducing environment of cancer tissues; (ii) they have the ability to coordinate ligands that can modulate their activity and have the same kinetics of ligand substitution in aqueous medium as that of Pt(II) complexes [33]; (iii) they have the possibility of occupying a large number of spatial positions due to its octahedral coordination geometry allowing to explore more and different ligands compared to platinum complexes; (iv) they reduced toxicity compared to platinum compounds and attributed to their ability to mimic iron binding to serum transferrin $[34,35]$ with higher selectivity for their targets due to selective uptake by the tumor compared with healthy tissues [36].

In the last year, several ruthenium compounds have been synthetized, and their antiproliferative activities and mechanism of action against several tumors characterized [8, 37-39], where cell membrane changes, cell death due to intrinsic apoptosis pathway and/or autophagic pathway, ROS induction, inhibition of topoisomerase I and II might be the cause of their cytotoxicity/antiproliferative activities [8, 39-44]. KP1019, trans-[Ru(In) $\left.{ }_{2} \mathrm{Cl}_{4}\right][\mathrm{InH}]$ (In = indazole), is known to bind transferrin and causes apoptosis through the mitochondrial pathway promoting the formation of ROS [45]. [Ru(bpy)(phpy)(dppz) $]^{+}$has found to be very cytotoxic against cancer cell line, the high affinity that presents for DNA leads to damages in the transcription 
factor NF- $\kappa B$ [46]. DW1/2 inhibits PI3K and GSK3- $\beta$, which leads to apoptosis mediated by the mitochondrial and p53 pathways [34]. Several $\mathrm{Ru}(\mathrm{II})$ complexes demonstrate high-binding affinity to DNA [47-49]. Some of these complexes appear to act by intercalation in the tumor cells, although in some cases it has been demonstrated that they can operate by DNA photocleavage [50-52]. Ruthenium complexes with polypyridine ligands such as 2,2-bipyridine (bpy), 1,10-phenanthroline (phen), and 2,2':6,2"-terpyridine (terpy) ligands have been largely explored as molecular DNA probes due to their photophysical properties and the ability of polypyridyl ligands to intercalate with DNA [35, 38, 53-55]. This type of ligands stabilizes the ruthenium metal ion in the oxidation state (II), resulting in solution-stable complexes of aqueous solution. Polypyridine ligands can confer photoluminescent properties to $\mathrm{Ru}$ (II) complexes, through a charge transfer between the metal and the ligand [56].

Cellular uptake of ruthenium complexes may occur through two mechanisms, energy dependent (endocytosis and active transport) and energy independent (facilitated diffusion and passive diffusion) [40]. For example, the complex $\left[\mathrm{Ru}(\mathrm{phen})_{2}(\text { mitatp) }]^{2+}\right.$ exhibited significant antitumor activity against several tumor cells, and flow cytometry experiments showed that the ruthenium compounds penetrate the cell membrane and accumulate in the nucleus, leading to cell cycle arrest and apoptosis [57]. The ruthenium compound $\left[\operatorname{Ru}(\mathrm{DIP})_{2}(\mathrm{dppz})\right]^{2+}$ showed cellular uptake through an energy-independent process [58]. Transferrin is used to transport iron centers into the cell, where the cancer cells have a high number of transferrin receptors compared to healthy cells [59]. Ruthenium complexes are transported by transferrin into cells by binding to two ruthenium centers. Upon entry into cells, the complex is released at acidic $\mathrm{pH}$. For example, KP1019 can use iron transport systems to locate itself inside the cell, binding to the DNA with a preference shown for G and A residues [36].

Several other ruthenium(II) metal complexes have been described in the literature that offers the possibility of designing molecules suitable for binding to specific biological targets, due to the fact that they exhibit a wide range of coordination numbers and possible geometries that allow the spatial organization of the different anions and organic ligands (for a review, See [60-64]). Examples with in vitro and in vivo antitumor activities are ruthenium(II) ( $\eta^{6}$ arene) complexes, such as $\left[\mathrm{Ru}\left(\eta^{6}-\mathrm{C}_{6} \mathrm{H}_{6}\right)(\right.$ dien$\left.)\right] \mathrm{Cl}$ (dien = ethylenediamine), and RAPTA, ruthenium(II)-arene complexes with the monodent ligand PTA (PTA = 1,3,5-triaza-7-phosphoadamantene) [46-48]. Stable bidentate chelating ligands (e.g., dien), more hydrophobic arene ligand (tetrahydroanthracene), and chloride ligand were associated with complexes with increased activity [65]. The RAPTA family comprises a monodent ligand PTA and the 76-arene ligand. Recently, the RAPTA-C complex has been shown to reduce the growth of primary tumors in preclinical models in ovarian and colorectal carcinomas through an antiangiogenic mechanism [66]. RAPTA-C binds selectively to the nucleus of the histone protein in the chromatin, resulting in the chloride binding of the ligands, and the inhibition of moderate growth in primary tumors in vivo is translated [67]. Sadler and coworkers studied ruthenium complexes (II)-arene with dien ligands ([Ru (n-6-arene) $\mathrm{Cl}$ (dien)] and demonstrated to be stable and soluble in water, exhibiting anticancer activity both in vitro and in vivo, including activity against cisplatin-resistant cancer cells. The dien ligand was used because of the similarities presented with the ammonium ligands in cisplatin, which are thought to contribute for cytotoxicity, forming a hydrogen bond with the DNA [68]. 
Of the numerous ruthenium complexes with antitumor action studied, only five $\mathrm{Ru}(\mathrm{III})$ complexes have entered clinical trials: trans-[ $\left.\mathrm{RuCl}_{4}(\mathrm{DMSO})(\mathrm{Im})\right][\mathrm{ImH}]$ (NAMI-A, Im = imidazole), KP1019, NKP-1339 (KP1019 sodium salt), KP1339, and Ru(II)-based therapeutic TLD1433 $[35,69]$. NAMI-A is an antimetastatic compound that reduces the metastases and prevents the spread of secondary tumors [70,71], whereas KP1019 is a cytotoxic compound effective against primary tumors [72]. NAMI-A and KP1019 are prodrugs that are activated in vivo by reduction to $\mathrm{Ru}(\mathrm{II})$ and well tolerated in clinical applications. The exact mode of action of both complexes is not clear, but it is known that they interact with DNA. NAMI-A and KP1019 successfully completed Phase I clinical trials; however, NAMI-A was recently withdrawn after Phase II due to its poor efficacy $[69,73]$. In addition, the combination of gemcitabine with NAMI-A allows entry into a new Phase II [70], but the combination was not well tolerated by patients and did not continue to Phase III [73]. KP1019 demonstrated low solubility that limited further development. NKP-1339 is a GRP78-targeted ruthenium-based anticancer compound and administered intravenously with promising results in solid tumors, such as colorectal carcinoma and neuroendocrine tumors [74]. The results obtained so far in clinical trials with some of these $\mathrm{Ru}(\mathrm{III})$ drug candidates fostered the increased interest in $\mathrm{Ru}(\mathrm{II})$ candidates for cancer therapy [40]. Recently, TLD1433, a mixed ligand Ru(II)-polypyridyl compound, entered Phase I of clinical trials for nonmuscle invasive bladder cancer treatment with photodynamic therapy (PDT) [75].

The interaction between the compounds and the plasma proteins is recognized as a crucial step in the access to bioavailability of metal complexes [32, 76, 77]. Serum albumin is the major protein in blood plasma acting as the carrier and distributor of many drugs because of its ability to bind reversibly to a variety of exogenous compounds [78, 79]. Their binding may increase solubility and prolong the in vivo half-life of the compounds, with a specific drug release at the target $[77,79,80]$. The interaction between compounds and proteins is usually analyzed by electronic absorption and fluorescence quenching. As various drugs bind to proteins in plasma, there has been an increasing investigation in the field of plasma protein binding (PPB). $\mathrm{Ru}(\mathrm{II})$ compounds bind preferentially to human serum albumin (HSA) and serum transferrin (Tf). These binding affinities showed that HSA appears to be the better partner [81]. KP1019 is known to strongly bind to serum proteins and hamper P-glycoprotein-mediated efflux, making this ruthenium therapeutic attractive for multidrugresistant tumor therapy [82]. RAPTA-C has shown a binding affinity to thioredoxin reductase and cathepsin B [83].

More recently, nanotechnology has provided numerous nanoplatforms that may act as vehicles for the active and more specific deliver of ruthenium(II) complexes toward cancer cells, namely $\mathrm{Ru}(\mathrm{II})$ - selenium nanoparticles, $\mathrm{Ru}(\mathrm{II})$ - gold nanomaterials, and $\mathrm{Ru}(\mathrm{II})$ - silica composite [39, 78-80]. Recently, Ru(II)-polypyridyl/thiol-selenium nanoparticles were found to be a powerful theranostic system, acting simultaneously as an imaging agent while fostering cancer cell death [84]. Chen and collaborators described a nanoparticle/Ru(II) polypyridyl system that is able to release a DNA-binding agent $\left[\mathrm{Ru}(\mathrm{bpy})_{2}(\mathrm{H} 2 \mathrm{O})_{2}\right]^{2+}$ upon laser irradiation [85]. In this sight, this nanosystem might improve ruthenium complex stability, distribution, and delivery specifically toward cancer cells providing a new avenue as a future therapeutic strategy [86]. 


\subsection{Copper}

Copper is an essential element in the organism, important for the function of enzymes and proteins involved in energy metabolism, respiration, and DNA synthesis [87]. This metal acts as a catalytic cofactor in several enzymes and is involved in hemoglobin formation, xenobiotics, catecholamines biosynthesis, collagen crosslinking, and oxidation-reduction reactions in which it reacts with molecular oxygen for the production of free radicals [87]. Copper-dependent enzymes, such as cytochrome $\mathrm{C}$ oxidase, superoxide dismutase, ferroxidases, monoamine oxidase, and dopamine b-monooxygenase, are involved in ROS neutralization. In addition, efflux of anticancer drugs such as cisplatin employs specific copper efflux transporters ATP7A and ATP7B, together with multidrug efflux pumps belonging to the $\mathrm{ABC}$ superfamily [e.g., P-glycoprotein (Pgp, ABCB1) and multidrug resistance protein 2 (MRP2, ABCC2)] [88, 89].

Copper complexes are the most studied transition metal complexes for their antitumor properties because endogenous metal ions may lead to less systemic toxicity. The properties of the copper complexes are determined by the nature of their ligands, which themselves may exhibit antiproliferative activity [87]. Several $\mathrm{Cu}$ (II) complexes with a variety of ligands containing N, S, or $\mathrm{O}$ have been developed, demonstrating different mechanisms for their antitumor activity [6, $90,91]$. The ligands neutralize the electrical charge of the copper ion and facilitate the transport of the complex through the cell membrane, interacting noncovalently with proteins or intercalating into the DNA molecule [92]. Copper complexes are capable of inducing DNA breaks through hydrolytic or oxidative cleavages [93-97]. Recently, a copper(II) complex $\left[\mathrm{Cu}\left(\mathrm{C}_{20} \mathrm{H}_{22} \mathrm{NO}_{3}\right)_{2}\right] \cdot \mathrm{H}_{2} \mathrm{O}$ was synthesized, and its mechanism of action evaluated by spectroscopic methods, showing that the complex binds to calf-thymus DNA through a partial intercalation and presents a static quenching process as binding mechanism. The cytotoxicity evaluation in cancer cell lines showed an enhanced cytotoxicity compared with the Schiff base ligand; thus, a positive synergetic effect may be occurring [98]. Horman et al. developed functionalized $\mathrm{Cu}$ (II) cyclen complexes with three (2-anthraquinonyl)methyl substituents that efficiently inhibited DNA and RNA syntheses resulting in high cytotoxicity accompanied by DNA condensation/aggregation phenomena [99]. Sigman et al. reported the first set of copper complexes with phen ligand with good cytotoxic activities [100]. The complex with two phen ligands is capable of cleaving the DNA by binding to the deoxyribose units, acting as a chemical nuclease [101]. Trejo-Solis et al. synthesized a class of $\mathrm{Cu}$ (II) complexes having the general formula $[\mathrm{Cu}(\mathrm{NN})(\mathrm{AA})] \mathrm{NO}_{3^{\prime}}$, wherein $\mathrm{NN}$ is phen or bipy, and AA is a nitrogen-oxygen donor or oxygen-oxygen donor ligand that is capable of inducing autophagy and programmed cell death cells by activation of ROS and JNK in glioma cells [102]. Another study demonstrated the antitumor properties of phen $\mathrm{Cu}$ (II) complexes with different alkyl chains. One of them showed a promising anticancer activity as well as antimetastatic and antiangiogenic potential, evidencing the versatility of $\mathrm{Cu}$ (II) complexes for cancer therapy [103].

A complex of Topo-I inhibitors, [Cu (N) L] Cl (N = phen, bipy or 5,50-dimethyl-2,20-bipyridine; $\mathrm{L}$ = doubly 5-triphenylphosphonium-methyl)-salicylaldehyde deprotonated hyde-benzoyl hydrazone, exhibits good cytotoxic activity against human lung and prostate adenocarcinoma cell lines [104], with the most active compound of this family being the one containing the fen motif.

Proteasome inhibition is another mechanism by which copper complexes exercise their antitumor activity. For example, $\mathrm{Cu}(\mathrm{II})$ complexes containing phen, 8-hydroxyquinolinate, pyrrolidine 
dithiocarbamate, or (pyridine-2-ylmethylamino)-methylphenolate have been shown to induce apoptosis by proteasome inhibition [105].

Copper complexes with thiosemicarbazone ligands have antitumor activity by inhibiting enzymatic activity and inducing cell apoptosis [106]. A Cu pro-drug derived from thiosemicarbazone based on the His146 residue in the IB subdomain of palmitic acid (PA)-modified human serum albumin (HSA-PA) was able to kill cancer cell by targeting DNA and proteins. Also, the efficient delivery of the $\mathrm{Cu}$ pro-drug was improved when the leaving group was replaced with His146 and coordinated with $\mathrm{Cu}^{2+}$ to form the HSA - PA complex. The HSA-PA complex showed better tolerance and a higher drug accumulation in the tumor, a stronger capacity for inhibiting tumor growth, and a lower toxicity in other tissues [107].

Casiopeína IIgly, one of the most promising drugs, shows a strong inhibition of cell proliferation against a glioma C6 cell line, in vivo as well as in vitro. This drug promotes cell death by an increase of ROS, with the consequence mitochondria damage followed by apoptosis caused through, caspase dependent and caspase independent pathways. Cas IIgly prevents malignant cells to continue with their life cycle, by inhibiting estrogen-mediated G1/S cell cycle progression [108, 109]. Currently, Cas IIIia is in Phase I clinical trials in Mexico, and experimental evidences demonstrated that the main mechanism of action is related to generation of ROS and DNA damage, through intercalation process [110].

Copper complexes are normally water insoluble. Therefore, the use of polymers/nanoparticles with suitable size can increase cellular internalization, distribution, and targeting of tumor cells with reduced toxicity in healthy cells. Intramolecular copper containing amphiphilic hyperbranched polytriazoles (mPEGhb-S-S-PTAs) was synthesized via $\mathrm{Cu}(\mathrm{I})$-catalyzed azidealkyne cycloaddition (CuAAC) reaction, forming copper-triazole coordination polyprodrugs that were used to delivery copper and for label-free cellular bioimaging, a novel theranostic (diagnostic and therapy simultaneously) application toward cancer therapy [111].

\subsection{Vanadium}

The major molecular targets for anticancer effects of vanadium compounds are the breakdown of cellular metabolism through the generation of ROS, GSH depletion, changes in cellular organelles, some pathways of signal transduction, and caspases, which can lead to cell cycle arrest and cell death. Pombeiro et al. synthesized two water-soluble heterometallic potassiumdioxidovanadium $(\mathrm{V})$ complexes, with an antiproliferative potential toward human colorectal carcinoma, lung, and breast adenocarcinoma cell lines. They demonstrate that the complex has a very high cytotoxic potential in the HCT116 cell line, a positive trait for future in vivo studies [112].

Vanadocene is a metallocene with a metal ion sandwiched between two cyclopentadienyl rings. Vanadocene dichloride, $\left[\mathrm{VCp}_{2} \mathrm{Cl}_{2}\right]$, was the first vanadocene that showed interesting results in preclinical studies [113]. This complex showed a strong activity in vitro against several tumor cells. In addition, in vivo studies demonstrated antitumor properties with vanadocene dichloride [114]. Some vanadocene derivatives present cytotoxic effect against T-lymphocytic leukemia cells, where the mechanism used evolves the DNA damage and p53 activation [115]. On the other hand, vanadocenes are effective agents against human testicular 
cell lines [36]. Vanadocenes containing fen ligands are promising anticancer agents, due to their high anticancer activity, solubility, and stability [37]. Currently, there are two complexes under preclinical trial $\left[\mathrm{VCp}_{2} \mathrm{Cl}_{2}\right]$ and Metvan, bis(4,7-dimethyl-1,10-phenanthroline) sulfatooxovanadium(IV). Metvan induces cell damage through apoptosis in several cell lines, with a special cytotoxic in ovarian and testicular cancer cell resistant to cisplatin. In vivo models, Metvan shows a promising anticancer activity on glioblastoma and breast cancer [116]. Cortizo et al. developed a delivery system of vanadium(IV) with aspirin (VOAspi) functionalized with poly(beta-propiolactone) (PbetaPL) films. VOAspi-PbetaPL film inhibited cell proliferation of UMR106 osteosarcoma cells in a dose-response manner [117].

\subsection{Iridium}

Iridium complexes are emerging as a class of anticancer agents. Novohradsky et al. studied the mechanisms of new cytotoxic iridium(III) complex in cancer cells. A half-sandwich cyclometallated $\operatorname{Ir}(\mathrm{III})$ complex $\left[\left(\eta^{5}-\mathrm{Cp}^{*}\right)(\mathrm{Ir})(7,8\right.$-benzoquinoline $\left.) \mathrm{Cl}\right]$ bearing a $\mathrm{C}^{\wedge} \mathrm{N}$ chelating ligand was designed and studied its uptake in ovarian cancer cells [118]. The temperature dependence and the coincubation with different substrates (such as ouabain, 2-deoxy-Dglucose and oligomycin, verapamil, reversan, and buthionine sulfoximine) indicate that an energy-independent passive diffusion and an energy-dependent transport play a partial role in the complex accumulation. Moreover, the competition experiments with $\mathrm{CuCl}_{2}$ suggested an involvement of Ctr1 pathway in the compound's uptake. The authors highlighted the importance of ATP-dependent processes and transport proteins, such as Na/K-ATPase for accumulation of Ir complexes. The iridium complexes may exert anticancer efficacy through various mechanisms including modulation of cellular redox reactions and inhibition of protein kinases. Recently, the cyclometalated iridium(III) complexes have gained increasing attention in bioimaging and biosensing applications due to their luminescence properties, for example, large Stokes shifts, long-lived luminescence, high quantum yields, and cell permeability [119].

\subsection{Titanium}

Since the 1970s, when the first titanium complex arises, a series of complexes containing titanium, $\mathrm{Ti}$, as a metal center have been synthesized and characterized, and some of them were shown to possess a wide spectrum of antitumor properties. Indeed, titanium complexes such as titanocene dichloride and octahedral species budotitane are promising anticancer results being translated to (pre)- and clinical trials. Preclinical trials had shown efficacy in a broad of tumors [113, 120]. Budotitane was investigated in Phase I trial, and pharmacokinetic study administered as i.v. infusion twice weekly with a starting dose of $100 \mathrm{mg} / \mathrm{m}^{2}$. However, no response was observed, but 17 of 18 patients have been resistant as they had received prior chemotherapy [121]. Titanocene dichloride showed promising results in Phase I trials with patients suffering from various cancer types. In one study, 40 patients with refractory solid malignancies the titanocene dichloride revealed a two minor responses (in bladder carcinoma and in nonsmall cell lung cancer), with dose-limiting toxicity side effect was nephrotoxicity [122]. Phase II trials were conducted at $270 \mathrm{mg} / \mathrm{m}^{2}$ every 3 weeks with 14 patients suffering from metastatic renal-cell carcinoma [123]. However, no significant response was noted, and the effectiveness of the treatment was limited in both cases. The instability under physiological 
condition and low solubility in aqueous media were the reasons of low activity in Phase II trials [124]. On the other hand, it was found that titanocene dichloride binds to DNA through the phosphate backbone, inhibiting DNA synthesis and leading to cell death [125]. The binding studies allowed to conclude that the cellular uptake of titanocene dichloride can be mediated by the iron transferrin transporter protein [126].

\subsection{Gallium}

The biological activity of gallium(III) arises from chemical similarity with iron(III). They have similar ionic radius, ionization potential, and electronic affinity [127]. However, the principal difference is that $\mathrm{Ga}(\mathrm{III})$ is nonreducible, whereas Fe(III) is reduced to Fe(II) under physiological condition [63].

Clinical Phase I and Phase II studies were performed on gallium nitrate, gallium chloride, and gallium maltolate. The first-generation gallium nitrate demonstrated, in several clinical trials, efficacy against bladder cancer and urothelium carcinoma, but these studies were discontinued due to ocular toxicity. The most promising results, come from the combination with vinblastine and ifosfamide, in a Phase II trial GA were effective in metastatic urothelial carcinomas at a dose of $300 \mathrm{mg} / \mathrm{m}^{2} / 24 \mathrm{~h}$ for 5 consecutive days. However, the duration of the responses was short at 20 weeks. This was associated with a high toxicity, and 11 of 27 patients had anemia and renal function alteration [128]. Oral gallium chloride seems to potentiate the action of cisplatin and etoposide. Oral gallium maltolate demonstrated higher bioavailability than gallium chloride. Preclinical studies have demonstrated synergy between Ga and paclitaxel [129]/gemcitabine [130]. Currently, two compounds are in clinical trials, gallium tris8-quinolinolate (KP46) and gallium tris-maltolate. KP46 contains the metal chelating agent 8-hydroxyquinoline and has an inhibitory effect in cell growth proliferation in vitro and in vivo superior to gallium salt. An oral formulation of KP46 demonstrates a pattern of cytotoxicity with synergism across a broad range of antitumor agents targeting the endoplasmic reticulum in multiple tumor types [131, 132]. Gallium maltolate, (3-hydroxy-2-methyl-4H-pyran4-onato) gallium, is an oral formulation for therapeutic use. This compound entry in Phase I demonstrated an oral bioavailability of about $27-47 \%$. At doses as high as $3500 \mathrm{mg} /$ day for 28-day cycles, no dose-limiting toxicity or drug-related adverse effects were observed [133]. However, this study was discontinued, and no new results were published. The mechanism of action of gallium(III) has been studied, and $\mathrm{Ga}^{3+}$ ions normally compete with $\mathrm{Fe}^{3+}$ for binding transferrin. Analyzing the biological pathways of gallium(III), it seems that its mechanism of action is associated with the inhibition of ribonucleotide reductase (RR). The enzyme RR produces during the transition from G1 to $S$ phase of the cell cycle and catalyzes the conversion of ribonucleotides to deoxyribonucleotides [63].

\subsection{Osmium}

Osmium(II) complexes are the heavier congeners of ruthenium, exhibit slower kinetic than ruthenium, and are substitution-inert (Os(II) and Os(III) complexes). In addition, they offer a more complex interaction with double-helical DNA. However, the reactivity of the Os(II)-arene complexes can be adjusted by the chemistry of the aqueous solution. Sadler et al. synthesized 
and developed osmium(II) arene complexes and proved their anticancer properties by systematically varying the chelating ligand in kinetics and thermodynamic reaction of the complexes $[134,135]$. These series of N,O-chelates ligands are important choices in the stability and cancer toxicity $[134,136]$. DNA-binding studies on a series of complexes of the type osmium(II)-arene have shown that these complexes bind to polymeric DNA, where some coordinate with guanine and others undergo quantitative reaction with DNA [137].

Recent work from Sadler and coworkers showed the distribution of osmium in cancer cells treated with relevant doses of $\mathrm{Os}^{\mathrm{II}}$ arene azopyridine complex by using X-ray fluorescence nanoprobe. This analysis shows localization of Os in mitochondria and not in nucleus and mobilization of calcium from endoplasmic reticulum [138]. Osmium compounds have been extensively exploited because they are capable to induce the formation of ROS, targeting mitochondria, and oxidize $\mathrm{NADH}$ to $\mathrm{NAD}^{+}$that lead to interference in the redox signaling pathways in cancer cells and are capable to interfere with cell cycle [69, 139]. In the last year, osmium analogs of the ruthenium anticancer agents, such as RAPTA-C, NAMI-A, and KP1019, have been developed. Therefore, osmium complexes demonstrated a good stability and inertness toward hydrolysis or ligand substitution. These are promising results for a future understanding of the mechanism of action of osmium compounds [134].

\subsection{Gold}

Gold in its elemental form is stable in an extensive range of conditions. Gold oxidation states range from -1 to +5 , but I and III are the most relevant. The coordination geometry of gold(I) complexes is not only generally linear accepting two ligands, but it can also coordinate three (trigonal) or four (tetragonal) ligands. Au(I) prefers to bind with thiolates, cyanides, phosphines, and soft halides [140]. Mainly due to the success of platinum compounds, and that gold(III) is isoelectronic with platinum(II) and forms similar square-planar complexes, a large number of gold(I) and gold(III) compounds have been studied for their anticancer activity [6]. Till now, auranofin [tetra-O-acetyl-b-D-(glucopyranosyl)thio](triethylphosphine) is the only gold compound ever approved. Used since 1985 as oral drug for the treatment of rheumatoid arthritis, its side effects, and restricted efficacy, it is only used for severe cases [141]. Some studies proposed its use as anticancer drug, and it is currently under several Phase I and II clinical trials to treat chronic lymphocytic leukemia (NCT01419691), lung cancer (NCT01737502), and glioblastoma (Glioblastoma).

The mode of action of auranofin is still not clear, and it is thought to be related with inhibition of thioredoxin reductase (TrxR). As gold has a high affinity for thiol and selenol groups, it tends to bind to amino acid residues, forming stable, irreversible adducts. TrxR is an essential enzyme in many cellular processes, mainly in balancing the redox homeostasis, controlling the level of ROS, and preventing DNA damage. As cancer cells tend to overexpress redox enzymes, they are mostly affected by auranofin. Selenoproteins, such as TrxR, when inhibited by auranofin compromise the mitochondria, leading to production of ROS that cause cellular oxidative stress and ultimately intrinsic apoptosis [141]. Several reports show the effect of auranofin against several tumors in vitro, including cisplatin resistant tumors [141]. Aurothiomalate is another gold compound, which is currently investigated in Phase I clinical trials to treat patients with advanced nonsmall cell lung cancer (NCT00575393). Its mechanism of action seems to be linked with protein kinase Ciota, which is overexpressed in 
nonsmall cell lung cancer, ovarian, and pancreatic cancers, playing a critical role in oncogenesis. Aurothiomalate has been shown to inhibit PKCiota signaling having potent antitumor activity in preclinical studies [142, 143]. Using the same mechanism, aurothioglucose also showed antitumor efficacy in vitro against nonsmall cell lung cancer cells [144]. For the cellular uptake, it was proposed that $\mathrm{Au}(\mathrm{I})$ enters the cell through albumin bond or through other thiol metabolites [144]. A recent study by Mármol proposes an alkynyl gold(I) complex $\left[\mathrm{Au}\left(\mathrm{C} \equiv \mathrm{C}-2-\mathrm{NC}_{5} \mathrm{H}_{4}\right)(\mathrm{PTA})\right]$ to treat colorectal carcinoma. In their study, using Caco-2 cells, gold complex enters the mitochondria and disrupts its normal function, triggering the necroptosis. Necrose-inducing compounds are mainly interesting as they are an alternative chemotherapy for apoptosis resistance tumors [145].

\subsection{Other complexes}

Cobalt complexes have normally two accessible oxidation states. Co(III) is kinetically inert, whereas $\mathrm{Co}(\mathrm{II})$ is labile. Some studies demonstrated that $\mathrm{Co}(\mathrm{III})$ complexes can act as carriers for selective delivery of drugs [69]. However, when $\mathrm{Co}(\mathrm{III})$ is reduced to $\mathrm{Co}(\mathrm{II})$, the molecule is released in its active form and can kill cancer cells [146]. Hexacarbonyl dicobalt and alkynes exhibit a promising activity of antitumor activity [147]. The activity is most pronounced when the alkyne is the propargyl ester of aspirin (CoASS), which inhibits the cyclooxygenase enzymes COX-1 and COX-2 [147, 148]. It was shown that CoASS itself inhibits COX-1 and COX-2 more strongly than ASA alone and enhanced the cytotoxicity against breast cancer cell line [148]. The development of new complexes bearing different types of pyrazole-based ligands demonstrated the potential use of these complexes as antiproliferative agents [149].

A new compound $\mathrm{CoCl}\left(\mathrm{H}_{2} \mathrm{O}\right)$ (phendione) $\left.{ }_{2}\right]\left[\mathrm{BF}_{4}\right]$ (phendione = 1,10-phenanthroline-5,6-dione) (TS265) was demonstrated to induce cell cycle arrest in $S$ phase with a subsequent cell death by apoptosis and high cytotoxicity against colorectal carcinoma cell [76]. Fernandes et al. evaluated the efficiency of two metal compounds [ $\left.\mathrm{Zn}(\mathrm{DION})_{2}\right] \mathrm{Cl}$ (TS262, DION =1,10-phenanthroline-5,6-dione) and TS265 and the application of AuNPs as a drug delivery system to improve the anticancer efficacy of these compounds in a new canine mammary tumor (FR37CMT) [150]. The same group formulated a multifunctional nanovectorization system using gold nanoparticles to enhance cytotoxic of TS265. This nanoformulation efficient delivered the cytotoxic cargo in a controlled selective manner [151]. Two mononuclear $\mathrm{Ni}^{\mathrm{II}}$ and $\mathrm{Mn}^{\mathrm{II}}$ compounds with a "scorpionate" type precursor demonstrated to induce damage in ovarian cancer cells through ROS accumulation. In addition, the mononuclear $\mathrm{Ni}^{\mathrm{II}}$ compound induced mitochondria dysfunction and autophagy cell death [5].

Although the intensive study of transition metals is focused on a specific biomolecular target, some complexes are developed for other purposes. For example, palladium-porphyrin complex (TOOKAD-soluble) acts as a photosensitizer and has progressed to Phase III clinical trial for the photodynamic treatment of prostate cancer (NCT01875393). Phase II clinical trials were evaluated the efficacy and safety of a single dose of the drug and light dosage combination of TOOKAD ${ }^{\circledR}$ Soluble in the focal treatment of patients with localized prostate cancer, 6 months after treatment. Positive results obtained at 6-month negative biopsies were acquire. This complex has a dual role; that is, it provides the ideal photophysical properties to the porphyrin and is inert enough not to be displaced during therapy (Table 1) [152]. 


\begin{tabular}{|c|c|c|c|c|}
\hline Name & Description & Target cancer & $\begin{array}{l}\text { Approved/clinical } \\
\text { trial }\end{array}$ & Refs. \\
\hline Platinol & Cisplatin & $\begin{array}{l}\text { Metastatic testicular, } \\
\text { ovarian and bladder cancers }\end{array}$ & FDA approval & [153] \\
\hline Paraplatin & Carboplatin & Advanced ovarian cancer & FDA approval & [153] \\
\hline Eloxatin & Oxaliplatin & $\begin{array}{l}\text { Advanced colorectal cancer } \\
\text { in combination with 5-FU } \\
\text { and leucovorin }\end{array}$ & FDA approval & [153] \\
\hline Aqupla & Nedaplatin & Urological tumors & Approved in Japan & [153] \\
\hline Lobaplatin & $\begin{array}{l}\text { 1,2-Diammino-1- } \\
\text { methylcyclobutane- } \\
\text { platinum(II)-lactate }\end{array}$ & $\begin{array}{l}\text { Inoperable metastatic breast } \\
\text { and small cell lung cancer }\end{array}$ & Approved in China & [153] \\
\hline Heptaplatin & Cisplatin analogs & Gastric cancer & Approved in Korea & [154] \\
\hline Picoplatin & $\begin{array}{l}\text { 2-Methylpyridine analog of } \\
\text { cisplatin }\end{array}$ & $\begin{array}{l}\text { Colorectal cancer in } \\
\text { combination with } 5 \text {-FU and } \\
\text { leucovorin }\end{array}$ & Phase II & {$[11]$} \\
\hline Satraplatin & $\begin{array}{l}\text { Bis-(acetate)-ammine } \\
\text { dichloro-(cyclohexylamine) } \\
\text { platinum(IV) }\end{array}$ & $\begin{array}{l}\text { Colorectal cancer in } \\
\text { combination with 5-FU } \\
\text { and leucovorin/prostate } \\
\text { cancer in combination with } \\
\text { docetaxel }\end{array}$ & Phase II/III & [153] \\
\hline Lipoplatin & Liposomal form of cisplatin & $\begin{array}{l}\text { Locally advanced gastric } \\
\text { cancer/squamous cell } \\
\text { carcinoma of head and neck }\end{array}$ & Phase II/III & [155] \\
\hline ProLindac & $\begin{array}{l}\text { Oxaliplatin with hydrophilic } \\
\text { polymer }\end{array}$ & $\begin{array}{l}\text { Ovarian cancer/head and } \\
\text { neck cancer }\end{array}$ & Phase II/III & [153] \\
\hline NAMIA-A & $\mathrm{RuCl}_{4}(\mathrm{DMSO})(\mathrm{Im})$ & $\begin{array}{l}\text { Metastatic tumor (lung, } \\
\text { colorectal, melanoma, } \\
\text { ovarian, and pancreatic) } \\
\text { in combination with } \\
\text { gemcitabine }\end{array}$ & Phase II & [156] \\
\hline KP1019 & Trans-[Ru(In) $\left.)_{2} \mathrm{Cl}_{4}\right][\mathrm{InH}]$ & Advanced colorectal cancer & Phase I & {$[157]$} \\
\hline NKP-1339 & KP1019 sodium salt & $\begin{array}{l}\text { Colorectal carcinoma and } \\
\text { neuroendocrine tumors }\end{array}$ & Phase I & [74] \\
\hline TLD1433 & $\begin{array}{l}\text { Ru(II)-polypyridyl } \\
\text { compound }\end{array}$ & $\begin{array}{l}\text { Nonmuscle invasive } \\
\text { bladder cancer treatment } \\
\text { with photodynamic therapy } \\
\text { (PDT) }\end{array}$ & Phase I & [75] \\
\hline Aurothiomalate & Gold compound & $\begin{array}{l}\text { Advanced nonsmall cell } \\
\text { lung cancer }\end{array}$ & Phase I & [158] \\
\hline Auranofin & $\begin{array}{l}\text { TetraO-acetyl-b-D- } \\
\text { (glucopyranosyl)thio] } \\
\text { (triethylphosphine) }\end{array}$ & $\begin{array}{l}\text { Chronic lymphocytic } \\
\text { leukemia, lung cancer, and } \\
\text { glioblastoma }\end{array}$ & Phase I/II & [141] \\
\hline CasII-gly & Casiopeína & Cervical cancer cell & Phase I in Mexico & [159] \\
\hline KP46 & Gallium tris-8-quinolinolate & Solid tumors & Phase I & [132] \\
\hline
\end{tabular}




\begin{tabular}{lllll}
\hline Name & Description & Target cancer & $\begin{array}{l}\text { Approved/clinical } \\
\text { trial }\end{array}$ & Refs. \\
\hline $\begin{array}{l}\text { TOOKAD } \\
\text { Soluble }\end{array}$ & $\begin{array}{l}\text { Palladium-porphyrin } \\
\text { complex }\end{array}$ & $\begin{array}{l}\text { palladium-porphyrin } \\
\text { complex }\end{array}$ & Phase III & {$[152]$} \\
$\begin{array}{l}\text { Gallium } \\
\text { tris-maltolate }\end{array}$ & $\begin{array}{l}\text { (3-Hydroxy-2-methyl-4H- } \\
\text { pyran-4-onato) gallium }\end{array}$ & Hepatocellular carcinoma & Phase I & {$[160]$} \\
\hline
\end{tabular}

Table 1. Clinical approved/undergoing clinical trials and metal compounds for anticancer therapeutic application.

\section{Conclusion}

Since the discovery of cisplatin, coordination complexes have been widely used in cancer therapy. Thirty years after its approval as a chemotherapeutic agent by the FDA, cisplatin remains to be one of the best-selling anticancer agents. Thousands of metal compounds have been described since then with only a few passing for clinical trials and even less getting approval. Both the high costs translating a promising drug to the clinic and the focus of pharma to go for new targeted therapies with minimum side effects instead of new cytotoxic agents can explain the current stall in the discovery of novel metal anticancer drugs. Despite the significant efforts in cancer treatment to increase efficacy without promoting side effects and/or resistance by cancer cells, cancer remains one of the major causes of death worldwide. To overcome this fatality, the identification of unique cellular and biochemical features of each tumor and the knowledge of the molecular mechanisms and biological targets of anticancer agents have, together, brought up the necessity for both synthesis and evaluation of new compounds with more promising antiproliferative potential with specific intracellular targets in cancer cells. The success of clinical treatment sparked interest in platinum compounds and other complexes $(\mathrm{Ru}, \mathrm{Cu}, \mathrm{Au}$, and $\mathrm{Co})$ containing metal ions to be used as anticancer agents. Well-established in vitro and in vivo studies, such as those shown in this chapter, are extremely important because the interest of a better quality of treatment is increasingly demanded. In addition to the development of more effective drugs, novel nanoscale drug delivery systems showing improved pharmacokinetic and pharmacodynamic properties, such as increased bioavailability, have emerged in the last decade as promising solutions for the required therapeutic efficacy. Combination of new metal complexes with known chemotherapeutic agents already in the market targeting different cellular pathways in a nanostructure may provide a new avenue and the future for cancer therapy.

\section{Acknowledgements}

This work was supported by the Unidade de Ciências Biomoleculares Aplicadas-UCIBIO, which is financed by national funds from FCT/MEC (UID/Multi/04378/2013) and cofinanced by the ERDF under the PT2020 Partnership Agreement (POCI-01-0145-FEDER-007728). PP also acknowledges FCT-MCTES grant PD/BD/105734/2014. 


\section{Conflict of interest}

Authors declare no conflict of interests.

\section{Author details}

Pedro Pedrosa ${ }^{\dagger}$, Andreia Carvalho $^{\dagger}$, Pedro V. Baptista and Alexandra R. Fernandes*

*Address all correspondence to: ma.fernandes@fct.unl.pt

UCIBIO, Department of Life Sciences, Faculty of Science and Technology, NOVA University of Lisbon, Caparica, Portugal

+ Both authors contributed equally

\section{References}

[1] Wenjie M, Qiong W. Applications of metal nanoparticles in medicine/metal nanoparticles as anticancer agents. In: Metal Nanoparticles [Internet]. Weinheim: Wiley-Blackwell; 2017. pp. 169-190. Available from: https://onlinelibrary.wiley.com/doi/abs/10.1002/9783527807093.ch7

[2] Pricker SP. Medical uses of gold compounds: Past, present and future. Gold Bulletin [Internet]. 1996;29(2):53-60. DOI: 10.1007/BF03215464

[3] Jungwirth U, Kowol CR, Keppler BK, Hartinger CG, Berger W, Heffeter P. Anticancer activity of metal complexes: Involvement of redox processes. Antioxidants \& Redox Signaling. Aug 2011;15(4):1085-1127

[4] Frezza M, HindoS, Chen D, DavenportA, SchmittS, Tomco D, et al. Novel metals and metal complexes as platforms for cancer therapy. Current Pharmaceutical Design. Jun 2010; 16(16):1813-1825

[5] Das K, Beyene BB, Datta A, Garribba E, Roma-Rodrigues C, Silva A, et al. EPR and electrochemical interpretation of bispyrazolylacetate anchored $\mathrm{Ni}$ (ii) and $\mathrm{Mn}$ (ii) complexes: Cytotoxicity and anti-proliferative activity towards human cancer cell lines. New Journal of Chemistry [Internet]. 2018;42(11):9126-9139. DOI: 10.1039/C8NJ01033A

[6] Maron A, Czerwinska K, Machura B, Raposo L, Roma-Rodrigues C, Fernandes AR, et al. Spectroscopy, electrochemistry and antiproliferative properties of $\mathrm{Au}$ (iii), $\mathrm{Pt}(\mathrm{ii})$ and $\mathrm{Cu}$ (ii) complexes bearing modified 2,2[prime or minute]:6[prime or minute],2[prime or minute][prime or minute]-terpyridine ligands. Dalton Transactions [Internet]. 2018;47(18): 6444-6463. DOI: 10.1039/C8DT00558C

[7] Martins M, Baptista PV, Mendo AS, Correia C, Videira P, Rodrigues AS, et al. In vitro and in vivo biological characterization of the anti-proliferative potential of a cyclic trinuclear organotin(iv) complex. Molecular BioSystems [Internet]. 2016;12(3):1015-1023. Available from: http://www.ncbi.nlm.nih.gov/pubmed/26842219 
[8] Lenis-rojas OA, Roma-rodrigues C, Fernandes AR, Marques F, Pe D, Ferna A. Dinuclear RuII(bipy)2 derivatives: Structural, biological, and in vivo zebrafish toxicity evaluation. Inorganic Chemistry. 2017;56(12):7127-7144

[9] Johnstone TC, Suntharalingam K, Lippard SJ. The next generation of platinum drugs: Targeted $\mathrm{Pt}(\mathrm{II})$ agents, nanoparticle delivery, and $\mathrm{Pt}(\mathrm{IV})$ prodrugs. Chemical Reviews [Internet]. Mar 9, 2016;116(5):3436-3486. DOI: 10.1021/acs.chemrev.5b00597

[10] Johnstone TC, Park GY, Lippard SJ. Understanding and improving platinum anticancer drugs-Phenanthriplatin. Anticancer Research. Jan 2014;34(1):471-476

[11] Wheate NJ, Walker S, Craig GE, Oun R. The status of platinum anticancer drugs in the clinic and in clinical trials. Dalton Transactions. Sep 2010;39(35):8113-8127

[12] Ndagi U, Mhlongo N, Soliman ME. Metal complexes in cancer therapy-An update from drug design perspective. Drug Design, Development and Therapy. 2017;11:599-616

[13] Johnstone TC, Suntharalingam K, Lippard SJ. Third row transition metals for the treatment of cancer. Philosophical Transactions of The Royal Society A Mathematical Physical and Engineering Sciences. Mar 2015;373(2037):20140185

[14] Shen D-W, Pouliot LM, Hall MD, Gottesman MM. Cisplatin resistance:A cellular self-defense mechanism resulting from multiple epigenetic and genetic changes. Pharmacological Reviews. Jul 2012;64(3):706-721

[15] Crul M, Schellens JHM, Beijnen JH, Maliepaard M. Cisplatin resistance and DNA repair. Cancer Treatment Reviews [Internet]. 1997;23(5):341-366. Available from: http://www. sciencedirect.com/science/article/pii/S0305737297900323

[16] Chen HHW, Kuo MT. Role of glutathione in the regulation of cisplatin resistance in cancer chemotherapy. Metal-Based Drugs [Internet]. Sep 14, 2010;2010:430939. Available from: http://www.ncbi.nlm.nih.gov/pmc/articles/PMC2946579/

[17] Shanta D, Lippard SJ. Current status and mechanism of action of platinum-based anticancer drugs. In: Bioinorganic Medicinal Chemistry [Internet]. Weinheim: WileyBlackwell; 2011. pp. 79-95. Available from: https://onlinelibrary.wiley.com/doi/abs/ 10.1002/9783527633104.ch3

[18] Hall MD, Amjadi S, Zhang M, Beale PJ, Hambley TW. The mechanism of action of platinum (IV) complexes in ovarian cancer cell lines. Journal of Inorganic Biochemistry [Internet]. 2004;98(10):1614-1624. Available from: http://www.sciencedirect.com/science/article/pii/ S0162013404001916

[19] Sousa de GF, Wlodarczyk SR, Monteiro G. Carboplatin: Molecular mechanisms of action associated with chemoresistance. Brazilian Journal of Pharmaceutical Sciences [Internet]. 2014;50:693-701. Available from: http://www.scielo.br/scielo.php?script= sci_arttext\&pid=S1984-82502014000400693\&nrm=iso

[20] Nakamura T, Ueda T, Oishi M, Nakanishi H, Fujihara A, Naya Y, et al. Salvage combined chemotherapy with paclitaxel, ifosfamide and nedaplatin for patients with advanced germ cell tumors. International Journal of Urology. Mar 2015;22(3):288-293 
[21] McKeage MJ. Lobaplatin: A new antitumour platinum drug. Expert Opinion on Investigational Drugs [Internet]. Jan 1, 2001;10(1):119-128. DOI: 10.1517/13543784.10.1.119

[22] Peng Y, Liu Y-E, REN X-C, Chen X-J, Su H-L, Zong J, et al. A phase I clinical trial of dose escalation of lobaplatin in combination with fixed-dose docetaxel for the treatment of human solid tumours that had progressed following chemotherapy. Oncology letters [Internet]. Jan 5, 2015;9(1):67-74. Available from: http://www.ncbi.nlm.nih.gov/pmc/ articles/PMC4246893/

[23] Sternberg CN, Whelan P, Hetherington J, Paluchowska B, Slee PHTJ, Vekemans K, et al. Phase III trial of satraplatin, an oral platinum plus prednisone vs. prednisone alone in patients with hormone-refractory prostate cancer. Oncology. 2005;68(1):2-9

[24] Hamilton G, Olszewski U. Picoplatin pharmacokinetics and chemotherapy of non-small cell lung cancer. Expert Opinion on Drug Metabolism \& Toxicology [Internet]. Oct 1, 2013;9(10):1381-1390. DOI: 10.1517/17425255.2013.815724

[25] Eckardt JR, Bentsion DL, Lipatov ON, Polyakov IS, Mackintosh FR, Karlin DA, et al. Phase II study of picoplatin as second-line therapy for patients with small-cell lung cancer. Journal of Clinical Oncology. Apr 2009;27(12):2046-2051

[26] Boulikas T. Clinical overview on lipoplatin: A successful liposomal formulation of cisplatin. Expert Opinion on Investigational Drugs. Aug 2009;18(8):1197-1218

[27] Nowotnik DP, Cvitkovic E. ProLindac ${ }^{\mathrm{TM}}$ (AP5346): A review of the development of an HPMA DACH platinum polymer therapeutic. Advanced Drug Delivery Reviews [Internet]. 2009;61(13):1214-1219. DOI: 10.1016/j.addr.2009.06.004

[28] Silva J, Sebastião A, Videira PA, Lasri J, Januário A, Pombeiro AJL, et al. Characterization of the antiproliferative potential and biological targets of a trans ketoimine platinum complex. Inorganica Chimica Acta [Internet]. 2014;423:156-167. DOI: 10.1016/j.ica.2014.07.067

[29] Patra M, Johnstone TC, Suntharalingam K, Lippard SJ. A potent glucose-platinum conjugate exploits glucose transporters and preferentially accumulates in cancer cells. Angewandte Chemie (International Ed. in English). Feb 2016;55(7):2550-2554

[30] Awuah SG, Zheng Y-R, Bruno PM, Hemann MT, Lippard SJ. A Pt(IV) pro-drug preferentially targets indoleamine-2,3-dioxygenase, providing enhanced ovarian cancer immunochemotherapy. Journal of the American Chemical Society [Internet]. Dec 2, 2015;137(47): 14854-14857. DOI: 10.1021 jacs.5b10182

[31] Du J, Wei Y, Zhao Y, Xu F, Wang Y, Zheng W, et al. A photoactive platinum(IV) anticancer complex inhibits thioredoxin-Thioredoxin reductase system activity by induced oxidization of the protein. Inorganic Chemistry [Internet]. May 7, 2018;57(9):5575-5584. DOI: $10.1021 /$ acs.inorgchem.8b00529

[32] Demoro B, Almeida R, Marques F, Matos C, Otero L, Pessoa C, et al. Screening organometallic binuclear thiosemicarbazone ruthenium complexes as potential anti-tumour agents: Cytotoxic activity and human serum albumin binding mechanism. Dalton Transactions. 2013;42:7131-7146 
[33] Muhammad N, GuoZ. Metal-based anticancer chemotherapeuticagents. Current Opinion in Chemical Biology [Internet]. 2014;19(1):144-153. DOI: 10.1016/j.cbpa.2014.02.003

[34] Bergamo A, Gaiddon C, Schellens JHM, Beijnen JH, Sava G. Approaching tumour therapy beyond platinum drugs: Status of the art and perspectives of ruthenium drug candidates. Journal of Inorganic Biochemistry [Internet]. 2012;106(1):90-99. DOI: 10.1016/j.jin orgbio.2011.09.030

[35] Motswainyana WM, Ajibade PA. Anticancer activities of mononuclear ruthenium(II) coordination complexes. Advances in Chemistry. 2015;2015:21

[36] Clarke MJ, Zhu F, Frasca DR. Non-platinum chemotherapeutic metallopharmaceuticals. Chemical Reviews. Sep 1999;99(9):2511-2534

[37] Côrte-Real L, Mendes F, Coimbra J, Morais TS, Tomaz AI, Valente A, et al. Anticancer activity of structurally related ruthenium(II) cyclopentadienyl complexes. Journal of Biological Inorganic Chemistry. 2014;19(6):853-867

[38] Chen J, Li G, Peng F, Jie X, Dongye G, Zhong Y, et al. Investigation of inducing apoptosis in human lung cancer A549 cells and related mechanism of a ruthenium(II) polypyridyl complex. Inorganic Chemistry Communications [Internet]. 2016;69:35-39. Available from: http://linkinghub.elsevier.com/retrieve/pii/S1387700316301228

[39] Lenis-Rojas OA, Fernandes AR, Roma-Rodrigues C, Baptista PV, Marques F, PérezFernández D, et al. Heteroleptic mononuclear compounds of ruthenium(II): Synthesis, structural analyses, in vitro antitumor activity and in vivo toxicity on zebrafish embryos. Dalton Transactions [Internet]. 2016;45(47):19127-19140. Available from: http://xlink.rsc. org/?DOI=C6DT03591D

[40] Zeng L, Gupta P, Chen Y, Wang E, Ji L, Chao H, et al. The development of anticancer ruthenium(ii) complexes: From single molecule compounds to nanomaterials. Chemical Society Reviews [Internet]. 2017;46(19):5771-5804. DOI: 10.1039/C7CS00195A

[41] Thota S, Vallala S, Yerra R, Rodrigues DA, Raghavendra NM, Barreiro EJ. Synthesis, characterization, DNA binding, DNA cleavage, protein binding and cytotoxic activities of $\mathrm{Ru}(\mathrm{II})$ complexes. International Journal of Biological Macromolecules [Internet]. 2016;82: 663-670. Available from: http://www.sciencedirect.com/science/article/pii/S0141813015006601

[42] Ratanaphan A, Nhukeaw T, Hongthong K, Dyson PJ. Differential cytotoxicity, cellular uptake, apoptosis and inhibition of BRCA1 expression of BRCA1-defective and sporadic breast cancer cells induced by an anticancer ruthenium(II)-arene compound, RAPTA-EA1. Anti-Cancer Agents in Medicinal Chemistry. 2017;17(2):212-220

[43] Popolin CP, Reis JPB, Becceneri AB, Graminha AE, Almeida MAP, Correa RS, et al. Cytotoxicity and anti-tumor effects of new ruthenium complexes on triple negative breast cancer cells. PLoS One. 2017;12(9):e0183275

[44] Grozav A, Balacescu O, Balacescu L, Cheminel T, Berindan-Neagoe I, Therrien B. Synthesis, anticancer activity, and genome profiling of thiazolo arene ruthenium complexes. Journal of Medicinal Chemistry [Internet]. Nov 12, 2015;58(21):8475-8490. DOI: 10.1021/acs.jmed chem.5b00855 
[45] Li W, Jiang G-B, Yao J-H, Wang X-Z, Wang J, Han B-J, et al. Ruthenium(II) complexes: DNA-binding, cytotoxicity, apoptosis, cellular localization, cell cycle arrest, reactive oxygen species, mitochondrial membrane potential and western blot analysis. Journal of Photochemistry and Photobiology. B. Nov 2014;140:94-104

[46] Huang H, Zhang P, Yu B, Chen Y, Wang J, Ji L, et al. Targeting nucleus DNA with a cyclometalated dipyridophenazineruthenium(II) complex. Journal of Medicinal Chemistry [Internet]. Nov 13, 2014;57(21):8971-8983. DOI: 10.1021/jm501095r

[47] Putta VR, Chintakuntla N, Mallepally RR, Yaswanth VVN, Prakasham RS, Surya SS. Synthesis and evaluation of in vitro DNA/protein binding affinity, antimicrobial, antioxidant and antitumor activity of mononuclear $\mathrm{Ru}(\mathrm{II})$ mixed polypyridyl complexes. Journal of Fluorescence. 2015;26(1):225-240

[48] Busto N, Valladolid J, Martínez-Alonso M, Lozano HJ, Jalón FA, Manzano BR, et al. Anticancer activity and DNA binding of a bifunctional $\mathrm{Ru}(\mathrm{II})$ arene aqua-complex with the 2,4-diamino-6-(2-pyridyl)-1,3,5-triazine ligand. Inorganic Chemistry [Internet]. Sep 3, 2013;52(17):9962-9974. DOI: 10.1021/ic401197a

[49] Su W, Qian Q, Li P, Lei X, Xiao Q, Huang S, et al. Synthesis, characterization, and anticancer activity of a series of ketone-N4-substituted thiosemicarbazones and their ruthenium(II) arene complexes. Inorganic Chemistry [Internet]. Nov 4, 2013;52(21):12440-12449. DOI: 10.1021/ic401362s

[50] Liu Y, Li Z, Liang C, Yao J-H, Huang H-L. Cytotoxicity, apoptosis, cellular uptake, cell cycle arrest, photocleavage, and antioxidant activity of 1, 10-phenanthroline ruthenium(II) complexes 1. DNA and Cell Biology. 2011;30(10):839-848

[51] Wachter E, Heidary DK, Howerton BS, Parkin S, Glazer EC. Light-activated ruthenium complexes photobind DNA and are cytotoxic in the photodynamic therapy window. Chemical Communications. 2012;48:9649-9651

[52] Qian C, Wang J, Song C, Wang L, Ji L, Chao H. The induction of mitochondria-mediated apoptosis in cancer cells by ruthenium(II) asymmetric complexes. The Royal Society of Chemistry. 2013;5:844-854

[53] Han W, Dyson PJ. Classical and non-classical ruthenium-based anticancer drugs: Towards targeted chemotherapy. European Journal of Inorganic Chemistry. 2006;20:4003-4018

[54] Reddy MR, Reddy VP, Kumar PY, Srishailam A, Nambigari N, Satyanarayana S. Synthesis, characterization, DNA binding, light switch "On and Off", docking studies and cytotoxicity, of ruthenium(II) and cobalt(III) polypyridyl complexes. Journal of Fluorescence. 2014;24:803-817

[55] Brabec V, Nováková O. DNA binding mode of ruthenium complexes and relationship to tumor cell toxicity. Drug Resistance Updates. 2006;9:111-122

[56] Medici S, Peana M, Marina V, Lachowicz JI, Crisponi G, Antonietta M. Noble metals in medicine: Latest advances. Coordination Chemistry Reviews [Internet]. 2014;1-22. DOI: 10.1016/j.ccr.2014.08.002 
[57] Yu H-J, Chen Y, Yu L, Hao Z, Zhou L. Synthesis, visible light photocleavage, antiproliferative and cellular uptake properties of ruthenium complex $\left[\mathrm{Ru}(\mathrm{phen}) 2(\text { mitatp) }]^{2+}\right.$. European Journal of Medicinal Chemistry. Sep 2012;55:146-154

[58] Puckett CA, Barton JK. Mechanism of cellular uptake of a ruthenium polypyridyl complex. Biochemistry. Nov 2008;47(45):11711-11716

[59] Allardyce CS, Dyson PJ. Ruthenium in medicine: Current clinical uses and future prospects. Platinum Metals Review. 2001;45(2):62-69

[60] Alama A, Tasso B, Novelli F, Sparatore F. Organometallic compounds in oncology: Implications of novel organotins as antitumor agents. Drug Discovery Today. 2009;14:500-507

[61] Martins P, Marques M, Coito L, Pombeiro AJL, Baptista PV, Fernandes AR. Organometallic compounds in cancer therapy: Past lessons and future directions. Anti-Cancer Agents in Medicinal Chemistry [Internet]. 2014;14(9):1199-212. Available from: http://www.ncbi. nlm.nih.gov/pubmed/25173559

[62] Han W, Casini A, Sava G, Dyson PJ. Organometallic ruthenium-based antitumor compounds with novel modes of action. Journal of Organometallic Chemistry [Internet]. 2011; 696(5):989-998. DOI: 10.1016/j.jorganchem.2010.11.009

[63] Van Rijt SH, Sadler PJ. Current applications and future potential for bioinorganic chemistry in the development of anticancer drugs. Drug Discovery Today. 2009;14(December): 1089-1097

[64] Sadler PJ, Habtemariam A, Melchart M, Fernandez R, Parsons S, Oswald IDH, et al. Structure-activity relationships for cytotoxic ruthenium(II) arene complexes containing N,N-, N,O-, and O,O- chelating ligands. Journal of Medicinal Chemistry. 2006;49:6858-6868

[65] Kostova I. Ruthenium complexes as anticancer agents. Current Medicinal Chemistry. 2006;13:1085-1107

[66] Weiss A, Berndsen RH, Dubois M, Muller C, Schibli R, Griffioen A, et al. In vivo anti-tumor activity of the organometallic ruthenium(II)-arene complex [Ru(h6-p-cymene)-Cl2(pta)] (RAPTA-C) in human ovarian and colorectal carcinomas. Chemical Science. 2014;5:4742-4748

[67] Adhireksan Z, Davey GE, Campomanes P, Groessl M, Clavel CM, Yu H, et al. Ligand substitutions between ruthenium-cymene compounds can control protein versus DNA targeting and anticancer activity. Nature Communications. Mar 2014;5:3462

[68] Morris RRE, Aird RE, del Socorro MP, Chen H, Cummings J, Hughes ND, et al. Inhibition of cancer cell growth by ruthenium(II) arene complexes. Journal of Medicinal Chemistry. 2001;44(22):3616-3621

[69] Zhang P, Sadler PJ. Redox-active metal complexes for anticancer therapy. European Journal of Inorganic Chemistry. 2017;2017(12):1541-1548

[70] Gransbury GK, Kappen P, Glover CJ, Hughes JN, Levina A, Lay PA, et al. Comparison of KP1019 and NAMI-A in tumour-mimetic environments. Metallomics. 2016;8:762-773. DOI: 10.1039/C6MT00145A 
[71] Clavel CM, Paunescu E, Nowak-sliwinska P, Griffioen AW, Scopelliti R, Dyson PJ. Modulating the anticancer activity of ruthenium(II)-arene complexes. Journal of Medicinal Chemistry. 2015;58(8):3356-3365

[72] Bergamo A, Masi A, Jakupec MA, Keppler BK, Sava G. Inhibitory effects of the ruthenium complex KP1019 in models of mammary cancer cell migration and invasion. Metal-Based Drugs. 2009;2009:681270

[73] Leijen S, Burgers SA, Baas P, Pluim D, Tibben M. Phase I/II study with ruthenium compound NAMI-A and gemcitabine in patients with non-small cell lung cancer after first line therapy. Investigational New Drugs. 2015;33:201-214

[74] Flocke LS, Trondl R, Jakupec MA. Molecular mode of action of NKP-1339-a clinically investigated ruthenium-based drug - involves ER- and ROS-related effects in colon carcinoma cell lines. Investigational New Drugs [Internet]. 2016;34:261-268. DOI: 10.1007/ s10637-016-0337-8

[75] Abid M, Shamsi F, Azam A. Ruthenium complexes: An emerging ground to the development of metallopharmaceuticals for cancer therapy. Mini-Reviews in Medicinal Chemistry [Internet]. 2016;16(10):772-786. Available from: http://www.ncbi.nlm.nih.gov/ pubmed/26423699

[76] Luis D V, Ana S, Tomaz I, De Almeida RFM, Silva TFS, Borralho PM, et al. Insights into the mechanisms underlying the antiproliferative potential of a $\mathrm{Co}(\mathrm{II})$ coordination compound bearing 1, 10-phenanthroline-5, 6-dione: DNA and protein interaction studies. Journal of Biological Inorganic Chemistry 2014;19(6):787-803

[77] Pessoa JC, Tomaz I. Transport of therapeutic vanadium and ruthenium complexes by blood plasma components. Clujul Medical. 2010;1019(17):3701-3738

[78] Tian Z, Zang F, Luo W, Zhao Z, Wang Y, Xu X, et al. Spectroscopic study on the interaction between mononaphthalimide spermidine (MINS) and bovine serum albumin (BSA). Journal of Photochemistry and Photobiology B: Biology [Internet]. 2015;142:103-109. DOI: 10.1016/j.jphotobiol.2014.10.013

[79] Li D, Zhu M, Xu C, Ji B. Characterization of the baicalein e bovine serum albumin complex without or with $\mathrm{Cu} 2 \mathrm{p}$ or $\mathrm{Fe} 3 \mathrm{p}$ by spectroscopic approaches. European Journal of Medicinal Chemistry [Internet]. 2011;46(2):588-599. DOI: 10.1016/j.ejmech.2010.11.038

[80] Topala T, Bodoki A, Oprean L, Oprean R. Bovine serum albumin interactions with metal complexes. Clujul Medical. 2014;87(4):215-219

[81] Canovic P, Simovic AR, Radisavljevic S, Bratsos I, Demitri N, Mitrovic M, et al. Impact of aromaticity on anticancer activity of polypyridyl ruthenium(II) complexes: Synthesis, structure, DNA/protein binding, lipophilicity and anticancer activity. Journal of Biological Inorganic Chemistry. Oct 2017;22(7):1007-1028

[82] Heffeter P, Bock K, Atil B, Reza Hoda MA, Korner W, Bartel C, et al. Intracellular protein binding patterns of the anticancer ruthenium drugs KP1019 and KP1339. Journal of Biological Inorganic Chemistry. Jun 2010;15(5):737-748 
[83] Casini A, Gabbiani C, Sorrentino F, Rigobello MP, Bindoli A, Geldbach TJ, et al. Emerging protein targets for anticancer metallodrugs: Inhibition of thioredoxin reductase and cathepsin B by antitumor ruthenium(II)-arene compounds. Journal of Medicinal Chemistry. 2008;51(Ii):6773-6781

[84] Sun D, Liu Y, Yu Q, Zhou Y, Zhang R, Chen X, et al. The effects of luminescent ruthenium(II) polypyridyl functionalized selenium nanoparticles on bFGF-induced angiogenesis and AKT/ERK signaling. Biomaterials. Jan 2013;34(1):171-180

[85] Chen Y, Jiang G, Zhou Q, Zhang Y, Li K, Zheng Y, et al. An upconversion nanoparticle/ $\mathrm{Ru}$ (ii) polypyridyl complex assembly for NIR-activated release of a DNA covalent-binding agent. RSC Advances [Internet]. 2016;6(28):23804-23808. DOI: 10.1039/C6RA03396B

[86] Coimbra J, Mota C, Santos S, Baptista PV, Fernandes AR. Inorganic compounds going NANO. Annals of Medicinal Chemistry and Research. 2015;2(1):1010

[87] Marzano C, Pellei M, Tisato F, Santini C. Copper complexes as anticancer agents. AntiCancer Agents in Medicinal Chemistry. Feb 2009;9(2):185-211

[88] Samimi G, Katano K, Holzer AK, Safaei R, Howell SB. Modulation of the cellular pharmacology of cisplatin and its analogs by the copper exporters ATP7A and ATP7B. Molecular Pharmacology. Jul 2004;66(1):25-32

[89] Leslie EM, Deeley RG, Cole SPC. Multidrug resistance proteins: Role of P-glycoprotein, MRP1,MRP2, and BCRP(ABCG2)intissuedefense. Toxicology and Applied Pharmacology [Internet]. 2005;204(3):216-237. Available from: http://www.sciencedirect.com/science/ article/pii/S0041008X0400482X

[90] Sutradhar M, Rajeshwari -, Roy Barman T, Fernandes AR, Paradinha F, Roma-Rodrigues C, et al. Mixed ligand aroylhydrazone and N-donor heterocyclic Lewis base $\mathrm{Cu}(\mathrm{II})$ complexes as potential antiproliferative agents. Journal of Inorganic Biochemistry. Oct 2017;175:267-275

[91] Czerwinska K, Machura B, Kula S, Krompiec S, Erfurt K, Roma-Rodrigues C, et al. Copper(ii) complexes of functionalized 2,2[prime or minute]:6[prime or minute],2 [prime or minute][prime or minute]-terpyridines and 2,6-di(thiazol-2-yl)pyridine: Structure, spectroscopy, cytotoxicity and catalytic activity. Dalton Transactions [Internet]. 2017;46(29):9591-9604. DOI: 10.1039/C7DT01244F

[92] Iakovidis I, Delimaris I, Piperakis SM. Copper and its complexes in medicine: A biochemical approach. Molecular Biology International. 2011;2011:1-13

[93] Rajendiran V, Karthik R, Palaniandavar M, Stoeckli-Evans H, Periasamy VS, Akbarsha MA, et al. Mixed-ligand copper(II)-phenolate complexes: Effect of coligand on enhanced DNA and protein binding, DNA cleavage, and anticancer activity. Inorganic Chemistry [Internet]. 2007;46(20):8208-8221. Available from: http://www.ncbi.nlm.nih.gov/pubmed/17784750

[94] Li X-W, Zheng Y-J, Li Y-T, Wu Z-Y, Yan C-W. Synthesis and structure of new bicopper(II) complexes bridged by $\mathrm{N}$-(2-aminopropyl)-N'-(2-oxidophenyl)oxamide: The effects of terminal ligands on structures, anticancer activities and DNA-binding properties. European Journal of Medicinal Chemistry. Sep 2011;46(9):3851-3857 
[95] Chen Q-Y, Fu H-J, Zhu W-H, Qi Y, Ma Z-P, Zhao K-D, et al. Interaction with DNA and different effect on the nucleus of cancer cells for copper(II) complexes of N-benzyl di(pyridylmethyl)amine. Dalton Transactions. May 2011;40(17):4414-4420

[96] Gup R, GokceC,Akturk S. Copper(II) complexes with 4-hydroxyacetophenone-derived acylhydrazones: Synthesis, characterization, DNA binding and cleavage properties. Spectrochimica Acta. Part A, Molecular and Biomolecular Spectroscopy. Jan 2015;134: 484-492

[97] Barilli A, Atzeri C, Bassanetti I, Ingoglia F, Dall'Asta V, Bussolati O, et al. Oxidative stress induced by copper and iron complexes with 8-hydroxyquinoline derivatives causes paraptotic death of HeLa cancer cells. Molecular Pharmaceutics. Apr 2014;11(4):1151-1163

[98] Shokohi-Pour Z, Chiniforoshan H, Momtazi-Borojeni AA, Notash B. A novel Schiff base derived from the gabapentin drug and copper(II) complex: Synthesis, characterization, interaction with DNA/protein and cytotoxic activity. Journal of Photochemistry and Photobiology B: Biology [Internet]. 2016;162:34-44. DOI: 10.1016/j.jphotobiol.2016.06.022

[99] Hormann J, Malina J, Lemke O, Hülsey MJ, Wedepohl S, Potthoff J, et al. Multiply intercalator-substituted $\mathrm{Cu}(\mathrm{II})$ cyclen complexes as DNA condensers and DNA/RNA synthesis inhibitors. Inorganic Chemistry. 2018;57(9):5004-5012

[100] Sigman DS, Graham DR, D'Aurora V, Stern AM. Oxygen-dependent cleavage of DNA by the 1,10-phenanthroline . cuprous complex. Inhibition of Escherichia coli DNA polymerase I. The Journal of Biological Chemistry. Dec 1979;254(24):12269-12272

[101] Pivetta T, Cannas MD, Demartin F, Castellano C, Vascellari S, Verani G, et al. Synthesis, structural characterization, formation constants and in vitro cytotoxicity of phenanthroline and imidazolidine-2-thione copper(II) complexes. Journal of Inorganic Biochemistry. Mar 2011;105(3):329-338

[102] Trejo-Solis C, Jimenez-Farfan D, Rodriguez-Enriquez S, Fernandez-Valverde F, CruzSalgado A, Ruiz-Azuara L, et al. Copper compound induces autophagy and apoptosis of glioma cells by reactive oxygen species and JNK activation. BMC Cancer. Apr 2012;12:156

[103] Shi X, Chen Z, Wang Y, Guo Z, Wang X. Hypotoxic copper complexes with potent antimetastatic and anti-angiogenic activities against cancer cells. Dalton Transactions. 2018; 47(14):5049-5054

[104] Chew ST, Lo KM, Lee SK, Heng MP, Teoh WY, Sim KS, et al. Copper complexes with phosphonium containing hydrazone ligand: Topoisomerase inhibition and cytotoxicity study. European Journal of Medicinal Chemistry. Apr 2014;76:397-407

[105] Hindo SS, Frezza M, Tomco D, Heeg MJ, Hryhorczuk L, McGarvey BR, et al. Metals in anticancer therapy: Copper(II) complexes as inhibitors of the $20 \mathrm{~S}$ proteasome. European Journal of Medicinal Chemistry [Internet]. 2009;44(11):4353-4361. Available from: http://www.sciencedirect.com/science/article/pii/S0223523409003122 
[106] Tisato F, Marzano C, Porchia M, Pellei M, Santini C. Copper in diseases and treatments, and copper-based anticancer strategies. Medicinal Research Reviews. Jul 2010;30(4): 708-749

[107] Qi J, Zhang Y, Gou Y, Zhang Z, Zhou Z, Wu X, et al. Developing an anticancer copper(II) pro-drug based on the His146 residue of the human serum albumin carrier IIA subdomain. Molecular Pharmaceutics. 2016;13(5):1501-1507

[108] Hernandez-Esquivel L, Marin-Hernandez A, Pavon N, Carvajal K, Moreno-Sanchez R. Cardiotoxicity of copper-based antineoplastic drugs casiopeinas is related to inhibition of energy metabolism. Toxicology and Applied Pharmacology. Apr 2006;212(1):79-88

[109] Alemon-Medina R, Brena-Valle M, Munoz-Sanchez JL, Gracia-Mora MI, Ruiz-Azuara L. Induction of oxidative damage by copper-based antineoplastic drugs (Casiopeinas). Cancer Chemotherapy and Pharmacology. Jul 2007;60(2):219-228

[110] Ruiz-Azuara L, Bastian G, Bravo-Gómez ME, Cañas RC, Flores-Alamo M, Fuentes I, et al. Abstract CT408: Phase I study of one mixed chelates copper(II) compound, Casiopeina CasIIIia with antitumor activity and its mechanism of action. Cancer Research [Internet]. 2014;74(19 Supplement): CT408-CT408. Available from: http://cancerres.aacrjournals. org/content/74/19_Supplement/CT408

[111] Ban Q, Du J, Sun W, Chen J, Wu S, Kong J. Intramolecular copper-containing hyperbranched polytriazole assemblies for label-free cellular bioimaging and redox-triggered copper complex delivery. 2018;1800171:1-6

[112] Sutradhar M, Fernandes AR, Silva J, Mahmudov KT, da Silva MFC, Pombeiro AJL. Water soluble heterometallic potassium-dioxidovanadium $(\mathrm{V})$ complexes as potential antiproliferative agents. Journal of Inorganic Biochemistry [Internet]. 2016;155:17-25. DOI: 10.1016/j.jinorgbio.2015.11.010

[113] Harding MM, Mokdsi G. Antitumour metallocenes: Structure-activity studies and interactions with biomolecules. Current Medicinal Chemistry. Dec 2000;7(12):1289-1303

[114] Havelek R, Siman P, Cmielova J, Stoklasova A, Vavrova J, Vinklarek J, et al. Differences in vanadocene dichloride and cisplatin effect on MOLT-4 leukemia and human peripheral blood mononuclear cells. Medicinal Chemistry. Jul 2012;8(4):615-621

[115] Aubrecht J, Narla RK, Ghosh P, Stanek J, Uckun FM. Molecular genotoxicity profiles of apoptosis-inducing vanadocene complexes. Toxicology and Applied Pharmacology [Internet]. 1999;154(3):228-235. Available from: http://www.sciencedirect.com/science/ article/pii/S0041008X98985921

[116] Narla RK, Dong Y, Klis D, Uckun FM. Bis(4,7-dimethyl-1,10-phenanthroline) sulfatooxovanadium(I.V.) as a novel antileukemic agent with matrix metalloproteinase inhibitory activity. Clinical Cancer Research. Apr 2001;7(4):1094-1101 
[117] Cortizo MS, Alessandrini JL, Etcheverr SB, Cortizo AM. A vanadium/aspirin complex controlled release using a poly(beta-propiolactone) film. Effects on osteosarcoma cells. Journal of Biomaterials Science. Polymer Edition. 2001;12(9):945-959

[118] Novohradsky V, Liu Z, Vojtiskova M, Sadler PJ, Brabec V, Kasparkova J. Mechanism of cellular accumulation of an iridium(III) pentamethylcyclopentadienyl anticancer complex containing a C,N-chelating ligand. Metallomics. Mar 2014;6(3):682-690

[119] Lo KK-W, Chan BT-N, Liu H-W, Zhang KY, Li SP-Y, Tang TS-M. Cyclometalated iridium(iii) polypyridine dibenzocyclooctyne complexes as the first phosphorescent bioorthogonal probes. Chemical Communications [Internet]. 2013;49(39):4271-4273. DOI: $10.1039 / C 2 C C 36907 A$

[120] Caruso F, Rossi M. Antitumor titanium compounds. Mini Reviews in Medicinal Chemistry. Jan 2004;4(1):49-60

[121] Schilling T, Keppler KB, Heim ME, Niebch G, Dietzfelbinger H, Rastetter J, et al. Clinical phase I and pharmacokinetic trial of the new titanium complex budotitane. Investigational New Drugs. 1996;13(4):327-332

[122] Korfel A, Scheulen ME, Schmoll HJ, Grundel O, Harstrick A, Knoche M, et al. Phase I clinical and pharmacokinetic study of titanocene dichloride in adults with advanced solid tumors. Clinical Cancer Research. Nov 1998;4(11):2701-2708

[123] Lummen G, Sperling H, Luboldt H, Otto T, Rubben H. Phase II trial of titanocene dichloride in advanced renal-cell carcinoma. Cancer Chemotherapy and Pharmacology. 1998; 42(5):415-417

[124] Melendez E. Titanium complexes in cancer treatment. Critical Reviews in Oncology/ Hematology. Jun 2002;42(3):309-315

[125] Guo M, Guo Z, Sadler PJ. Titanium(IV) targets phosphoesters on nucleotides: Implications for the mechanism of action of the anticancer drug titanocene dichloride. Journal of Biological Inorganic Chemistry. Sep 2001;6(7):698-707

[126] Timerbaev AR, Hartinger CG, Aleksenko SS, Keppler BK. Interactions of antitumor metallodrugs with serum proteins: advances in characterization using modern analytical methodology. Chemical Reviews [Internet]. Jun 1, 2006;106(6):2224-2248. DOI: 10.1021/cr040704h

[127] Chitambar CR. Gallium-containing anticancer compounds. Future Medicinal Chemistry. 2012;4(10):1257-1272

[128] Senderowicz AM, Reid R, Headlee D, Abornathy T, Horti J, Lush RM, et al. A phase II trial of gallium nitrate in patients with androgen-metastatic prostate cancer. Urologia Internationalis. 1999;63(2):120-125

[129] Hata Y, Sandler A, Loehrer PJ, Sledge GWJ, Weber G. Synergism of taxol and gallium nitrate in human breast carcinoma cells: Schedule dependency. Oncology Research. 1994; 6(1):19-24 
[130] Myette MS, Elford HL, Chitambar CR. Interaction of gallium nitrate with other inhibitors of ribonucleotide reductase: Effects on the proliferation of human leukemic cells. Cancer Letters. Jul 1998;129(2):199-204

[131] Hofheinz RD, Dittrich C, Jakupec MA, Drescher A, Jaehde U, Gneist M, et al. Early results from a phase I study on orally administered tris(8-quinolinolato)gallium(III) (FFC11, KP46) in patients with solid tumors-A CESAR study (Central European Society for Anticancer Drug Research-EWIV). International Journal of Clinical Pharmacology and Therapeutics. Dec 2005;43(12):590-591

[132] Valiahdi SM, Heffeter P, Jakupec MA, Marculescu R, Berger W, Rappersberger K, et al. The gallium complex KP46 exerts strong activity against primary explanted melanoma cells and induces apoptosis in melanoma cell lines. Melanoma Research. Oct 2009;19(5):283-293

[133] Bernstein LR, Tanner T, Godfrey C, Noll B. Chemistry and pharmacokinetics of gallium maltolate, a compound with high oral gallium bioavailability. Metal-Based Drugs. 2000;7(1):33-47

[134] Peacock AFA, Sadler PJ. Medicinal organometallic chemistry: Designing metal arene complexes as anticancer agents. Chemistry, An Asian Journal. Nov 2008;3(11):1890-1899

[135] Peacock AFA, Habtemariam A, Fernández R, Walland V, Fabbiani FPA, Parsons S, et al. Tuning the reactivity of osmium(II) and ruthenium(II) arene complexes under physiological conditions. Journal of the American Chemical Society [Internet]. Feb 1, 2006; 128(5):1739-1748. DOI: 10.1021/ja055886r

[136] Peacock AFA, Parsons S, Sadler PJ. Tuning the hydrolytic aqueous chemistry of osmium arene complexes with $\mathrm{N}, \mathrm{O}$-chelating ligands to achieve cancer cell cytotoxicity. Journal of the American Chemical Society [Internet]. Mar 1, 2007;129(11):3348-3357. DOI: 10.1021/ja068335p

[137] Kostrhunova H, Florian J, Novakova O, Peacock AFA, Sadler PJ, Brabec V. DNA Interactions of monofunctional organometallic osmium(II) antitumor complexes in cell-free media. Journal of Medicinal Chemistry [Internet]. Jun 1, 2008;51(12):3635-3643. DOI: $10.1021 / j m 701538 \mathrm{w}$

[138] Sanchez-Cano C, Romero-Canelon I, Yang Y, Hands-Portman IJ, Bohic S, Cloetens P, et al. Synchrotron $\mathrm{X}$-ray fluorescence nanoprobe reveals target sites for organo-osmium complex in human ovarian cancer cells. Chemistry. Feb 2017;23(11):2512-2516

[139] Hanif M, Babak MV, Hartinger CG. Development of anticancer agents: Wizardry with osmium. Drug Discovery Today. Oct 2014;19(10):1640-1648

[140] Nobili S, Mini E, Landini I, Gabbiani C, Casini A, Messori L. Gold compounds as anticancer agents: Chemistry, cellular pharmacology, and preclinical studies. Medicinal Research Reviews. May 2010;30(3):550-580

[141] Roder C, Thomson MJ. Auranofin: Repurposing an old drug for a golden new age. Drugs in R\&D [Internet]. Mar 20, 2015;15(1):13-20. Available from: http://www.ncbi.nlm.nih. gov/pmc/articles/PMC4359176/ 
[142] Trani M, Sorrentino A, Busch C, Landström M. Pro-apoptotic effect of aurothiomalate in prostate cancer cells. Cell Cycle [Internet]. Jan 15, 2009;8(2):306-313. DOI: 10.4161/cc. 8.2 .7596

[143] Regala RP, Thompson EA, Fields AP. Atypical protein kinase Ciota expression and aurothiomalate sensitivity in human lung cancer cells. Cancer Research. Jul 2008;68(14):5888-5895

[144] Stallings-Mann M, Jamieson L, Regala RP, Weems C, Murray NR, Fields AP. A novel small-molecule inhibitor of protein kinase Ciota blocks transformed growth of nonsmall-cell lung cancer cells. Cancer Research [Internet]. 2006;66(3):1767-1774. Available from: http://cancerres.aacrjournals.org/content/66/3/1767

[145] Mármol I, Virumbrales-Muñoz M, Quero J, Sánchez-de-Diego C, Fernández L, Ochoa I, et al. Alkynyl gold(I) complex triggers necroptosis via ROS generation in colorectal carcinoma cells. Journal of Inorganic Biochemistry [Internet]. 2017;176:123-133. Available from: http://www.sciencedirect.com/science/article/pii/S0162013417304130

[146] Munteanu CR, Suntharalingam K. Advances in cobalt complexes as anticancer agents. Dalton Transactions [Internet]. 2015;44(31):13796-13808. DOI: 10.1039/C5DT02101D

[147] Ott I, Kircher B, Dembinski R, Gust R. Alkyne hexacarbonyl dicobalt complexes in medicinal chemistry and drug development. Expert Opinion on Therapeutic Patents [Internet]. Mar 1, 2008;18(3):327-337. DOI: 10.1517/13543776.18.3.327

[148] Trudu F, Amato F, Vaňhara P, Pivetta T, Peña-Méndez EM, Havel J. Coordination compounds in cancer: Past, present and perspectives. Journal of Applied Biomedicine [Internet]. 2015;13(2):79-103. Available from: http://www.sciencedirect.com/science/article/ pii/S1214021X15000095

[149] Silva TFS, Martins LMDRS, Guedes da Silva MFC, Fernandes AR, Silva A, Borralho PM, et al. Cobalt complexes bearing scorpionate ligands: Synthesis, characterization, cytotoxicity and DNA cleavage. Dalton Transactions. 2012;41(41):12888-12897

[150] Raposo LR, Roma-Rodrigues C, Jesus J, Martins LMDRS, Pombeiro AJ, Baptista PV, et al. Targeting canine mammary tumours via gold nanoparticles functionalized with promising Co(II) and Zn(II) compounds. Veterinary and Comparative Oncology. 2017;15(4):1537-1542

[151] Fernandes AR, Jesus J, Martins P, Figueiredo S, Rosa D, Martins LMRDRS, et al. Multifunctional gold-nanoparticles: A nanovectorization tool for the targeted delivery of novel chemotherapeutic agents. Journal of Controlled Release. 2017;245:52-61

[152] Azzouzi AR, Barret E, Bennet J, Moore C, Taneja S, Muir G, et al. TOOKAD(R) soluble focal therapy: Pooled analysis of three phase II studies assessing the minimally invasive ablation of localized prostate cancer. World Journal of Urology. Jul 2015;33(7):945-953

[153] Monneret C. Platinum anticancer drugs. From serendipity to rational design. Annales Pharmaceutiques Françaises [Internet]. 2011;69(6):286-295. DOI: 10.1016/j.pharma. 2011.10.001 
[154] Choi CH, Cha YJ, An CS, Kim KJ, Kim KC, Moon SP, et al. Molecular mechanisms of heptaplatin effective against cisplatin-resistant cancer cell lines: Less involvement of metallothionein. Cancer Cell International. 2004;4:1-12

[155] Apps MG, Choi EHY, Wheate NJ. The state-of-play and future of platinum drugs. Endocrine-Related Cancer. Aug 2015;22(4):R219-R233

[156] Alessio E. Thirty years of the drug candidate NAMI-A and the myths in the field of ruthenium anticancer compounds: A personal perspective. European Journal of Inorganic Chemistry. 2017;2017(12):1549-1560

[157] Alessio E, Messori L. The deceptively similar ruthenium(III) drug candidates KP1019 and NAMI-A have different actions. What did we learn in the past 30 years? Metal Ions in Life Sciences. Feb 2018;18:141-171

[158] Mansfield AS, Fields AP, Jatoi A, Qi Y, Adjei AA, Erlichman C, et al. Phase I dose escalation study of the PKCiota inhibitor aurothiomalate for advanced non-small-cell lung cancer, ovarian cancer, and pancreatic cancer. Anti-Cancer Drugs. Nov 2013;24(10):1079-1083

[159] Espinal-Enríquez J, Hernández-Lemus E, Mejía C, Ruiz-Azuara L. Network analysis shows novel molecular mechanisms of action for copper-based chemotherapy. Frontiers in Physiology. 2016;6(Jan):1-13

[160] Bernstein LR, van der Hoeven JJM, Boer RO. Hepatocellular carcinoma detection by gallium scan and subsequent treatment by gallium maltolate: Rationale and case study. Anti-Cancer Agents in Medicinal Chemistry [Internet]. 2011;11(6):585-590. Available from: http://www.ncbi.nlm.nih.gov/pubmed/21554205 
